\title{
Sustainable Metal ReCyCling SUPPLY Chains: Prioritizing Success Factors APPLYING COMBINED AHP \& PCA TECHNIQUES
}

\author{
Jitendar Khatri ${ }^{1}$ and Ashutosh Dash ${ }^{2}$ \\ ${ }^{1}$ Department of Operations Management, Management Development Institute (MDI), \\ Gurgaon, India \\ ${ }^{2}$ Department of Finance Management, Management Development Institute (MDI), \\ Gurgaon, India
}

\begin{abstract}
Triple Bottom Line (3 BL) Sustainability has been expressed as a tool in the hands of policy makers to achieve competitive advantage. Closed-Loop Supply Chain (CLSC) conceptualizes the design, control, and operation of the supply chain systems to recover the value from the product even after their useful life through the processes of reuse and recycle. Efficient management of CLSC operations in metal recycling industry will enhance $3 B L$ sustainability. The present study investigates and shortlists critical sustainability factors in metal recycling CLSC operations. The study applies Analytic Hierarchy Process $(A H P)$ to identify the most important factors and Principal Component Analysis (PCA) techniques to check the reliability and validity of these factors through statistical analysis. The study identifies five most important factors to achieve sustainability in metal recycling CLSC. Although the article is focused on the Indian metal recycling industry but factors can be relevant for researchers in other developing countries, where similar economic, social and environmental conditions exist.
\end{abstract}

\section{KEYWORD}

Analytic Hierarchy Process, Closed Loop Supply Chain, Principal Component Analysis, Triple Bottom Line, Sustainability

\section{INTRODUCTION}

During the first industrial revolution period (176-1820) and subsequent industrial revolutions traditional unit production methods were replaced by the mass production methods and manual operations were substituted with machines. These changes in production methods have lead to increasing growth in resource consumption all over the World. The large scale industrialization in the expanding global markets, coupled with increasing population, has created imbalance between the availability and consumption of natural resources. The simultaneous increase in demand and reduction in metallic resource reserves, the degradation of existing reserves, the uprooting of inhabitants associated with mining operations, the deteriorating natural environment, and rising awareness among public has compelled business, policy makers and governments to begin thinking in terms of sustainability. Sustainability is considered to consist of three components: the conservation of natural environment, benefits of the local communities and society at large and economic growth. Researchers argue assimilation of these three concepts into business policies and practices are of paramount importance for sustainable development (SD) [1], [2], [3]. Closed-Loop Supply Chain (CLSC) is one such practice adopted by businesses and it targets recovering the left over values from the product after it has served the intended 
purpose [4]. Researchers have highlighted the importance of identifying important factors which can contribute to 3-BL sustainability in metal recycling industry in order to achieve sustainable metal supply for future generations [5].

This current study investigates the most critical factors responsible for 3-BL sustainability in Indian metal recycling industry through application of Analytic Hierarchy Process (AHP) and Principal Component Analysis (PCA) methodology.

\section{LITERATURE REVIEW 2.1. Triple Bottom Line (3-BL) Sustainability}

In order to address the new challenges on natural resources; both perishable as well as nonperishable, by growing industrialization, businesses needs to ensure that their activities eliminate waste and become sustainable [6], [7]. Sustainability or Sustainable Development (SD) has been proposed as a tool for decision-makers to repay their due towards society by taking into account the balanced economic, environmental, and societal growth. After a thorough study of the consumption pattern of natural resources over a period of 30 years, in their famous book, Limits to Growth", researchers [8] warn that the world might collapse one day as it greatly relies on diminishing global resources and produces excessive emissions. The European Union (EU), considering the importance of sustainability, has urged member countries that current and future legislation must integrate sustainability into implementation orders. Many other countries are also introducing regulations that address sustainability issues [9]. In general terms, sustainability is expressed as a concept that enables the current generation meeting their requirements without harming the ability of future generations through thoughtful exploitation of resources [1] (WCED, 1987). Researchers suggest that by adopting simultaneous economic, ecological and societal factors of sustainability ( $3 \mathrm{BL}$ ) into business objectives, we can ensure future of next generations [3] [5] [10] [11]. While the economic aspect of the 3BL is widely understood and used in business and industry and its measurement criteria are also well defined, the environmental and social concepts are far less understood and practiced. However, most corporate are preparing to include societal and environmental objectives into their policies due to increased internal and external pressures [12].

\subsection{Closed-Loop Supply Chain and Triple Bottom Line Sustainability.}

Since the sub-processes of supply chain process involve the initial processing of raw material through final production and up to delivery of the product or services to potential customers, supply chain sustainability is considered as the single most important contributor towards business sustainability. Growing number of researchers and policy makers have started realizing that supply chain sustainability has the latent potential to realize 3-BL business objectives [13], [14]. Hence Sustainable Supply Chain Management (SSCM) has been defined as a strategic management function that incorporates societal and environmental objectives along with economic objectives for the successful long term successful performances of the organizations [15]. Successful SSCM demands the effective synchronization of available resources, business processes and stakeholders' needs into organization's vision for generating healthy returns on assets. Researchers and policy makers [16], [17] now agree that closing the loops are a prerequisite for supply chain sustainability whether it is measured in terms of economic, environment or societal context; and hence the concept of CLSC was introduced. CLSC operations are designed to recover efficiently the remaining values of the used products in the forward supply chains through reuse or recycling thus providing additional sustainability to supply chains [17] [18]. 


\subsubsection{Achieving Triple Bottom Line Sustainability through Closing Metal Supply Loop}

Researchers have identified major wastes and concerns that emerge in the metal forward supply chains, including supply chain disruption and discontinuity, inadequate or inconsistent product quality, unpredictable delivery times and substantial, unanticipated additional costs, including premium freights [19], [20], and [21]. On the other hand, closing the loop activities are mainly concerned with waste reduction through efficient collection, recycling and integration of the recyclable material/ products back into the manufacturing stream. Metal recycling advances the necessary conditions for promoting triple bottom line sustainability by conserving perishable virgin metal resources, reducing mineral processing energy consumption, reducing landfill requirements, and protecting natural environment and creating job opportunities [22], [23] [24]. The same researchers highlight the need for identifying important CLSC factors and addressing them to exploit the maximum latent potential for achieving sustainability.

\subsection{Review of Previous Research for Sustainability Studies in Supply chain.}

Research methodology is the research approach followed by the researcher from theoretical considerations to data collection and analysis [25], [26]. The intent of this section is twofold: First to review the literature on the sustainable supply chain operation and important factors identified and investigated previously by researchers. The second objective is to review research methodologies commonly used and also the less common methodologies with high potential research opportunities to investigate the triple bottom line sustainability in supply chains.

Conceptual /theory and case studies have been the most common methodological approaches to sustainability and supply chain relations study till date [27] [28]. Some authors specifically developed concepts and proposed frameworks in order to classify and deal with strategic issues in SCM and sustainability [29], [30], and CLSC uncertainties and sustainability relation[31], [32], [33] and in development of algorithm for simultaneous study of economic and environmental impacts of CLSC operations [34]. The other commonly used method for sustainability research in supply chain is the case study methodology since this methodology is most suitable for understanding the issues in a new research domain [35]. Researchers have applied this methodology to study different aspects of CLSC across various industry sectors [36], [37], and [38]. Another less common method used by researchers is analytical models for studying the supply chain and sustainability relationships. Literature points out a lack of multicriteria decision making (MCDM) approaches for green logistics and supply chain sustainability study [39], [14]. However quantitative studies have been done using different approaches for the study of sustainability phenomena in supply chain. This includes use of optimization concepts [40], Analytic Hierarchy Process (AHP) [41] [42], Fuzzy decision making [43]. Another less applied but promising research method suggested in literature is mixed method research [44], [45]. In the present study, researchers applied multi-methods approach or method triangulation in his study. This entailed the use of a combination of research instruments that includes interviews schedules, questionnaires guides, non-participant observation, and secondary data analysis.

\subsubsection{AHP Method}

The AHP is a multi-criteria decision making (MCDM) methodology, developed by T.L. Saaty [46] in 1980. Owing to its easy to understand and simple to apply methodology [47], [48], researchers have applied AHP methodology across a number of situations for studying sustainability and supply chain issues including sustainable supply chain technology evaluation and selection, performance measurement system development and prioritization of environmental factors [24], [47], [48], [49], [50]. 
This multi-criteria methodology disintegrates a complex decision-making issue into subproblems/ sub-sub problems, which are easy to understand and diagnose. The subjective choices of experts are assigned numerical values through ranking on a scale developed by Saaty [46]. The pair-wise comparisons of various criteria generated at previous step are organized into a square matrix. The diagonal elements of matrix are 1. In order to assign relative values to various factors under consideration, Principal Eigen values and maximum Eigen values $\left(\lambda_{\max }\right)$, are calculated. Consistencies in the diagnosis of the experts are verified through calculating Consistency Index (CI) and Consistency Ratio (CR) values, applying following steps [46]

$\mathrm{CI}=\left(\lambda_{\max }-\mathrm{n}\right) /(\mathrm{n}-1)$

Where, $\lambda_{\max }$ is the maximum Eigen value of judgment matrix and $\mathrm{n}$ is number of evaluated criteria. Consistency Ratio (CR) is calculated as:

$\mathrm{CR}=\mathrm{CI} / \mathrm{RI}$

$\mathrm{RI}$ value is fixed for a given sample size. In general, a CR up to 0.10 is regarded to be acceptable value [24], [46].

\subsubsection{Principal Component Analysis Method}

Principal component analysis (PCA), a multivariate methodology, is applied when researcher needs to contract numbers of observed variables into comparatively fewer factors contributing towards appreciable amount of data variability [51]. This methodology compiles changes in the observed data, to a group of unrelated factors each of which is an aggregate of original variables and are known as principal components (PC). Researchers have applied multivariate techniques for study of supply chain sustainability [52], [53] in electronic industry.

\section{RESEARCH DESIGN}

Our research methodology is adapted from the work of Kim et al. [54], who studied most important factors for growth of retail sector supply chain in Korea by applying multi-criteria analysis technique.

This study consisted of two surveys: First an AHP survey and then a general survey. The first survey was aimed at prioritizing and assigning quantitative values to the sustainability factors in CLSC operations identified from the literature and the field work. A conceptual CLSC sustainability model was developed. A general survey was undertaken to statistically check the validity and reliability of the previously prioritized factors. Principal Component Analysis (PCA) methodology was employed to extract the most common factors. The commonality of the factors in the two methods validates the conceptual model developed through AHP technique. Prior to large scale survey of CLSC practices and sustainability performances, a pilot study was first conducted to test the suitability of proposed survey instrument prior to sending it out. The procedural steps are explained in Fig. 1. 


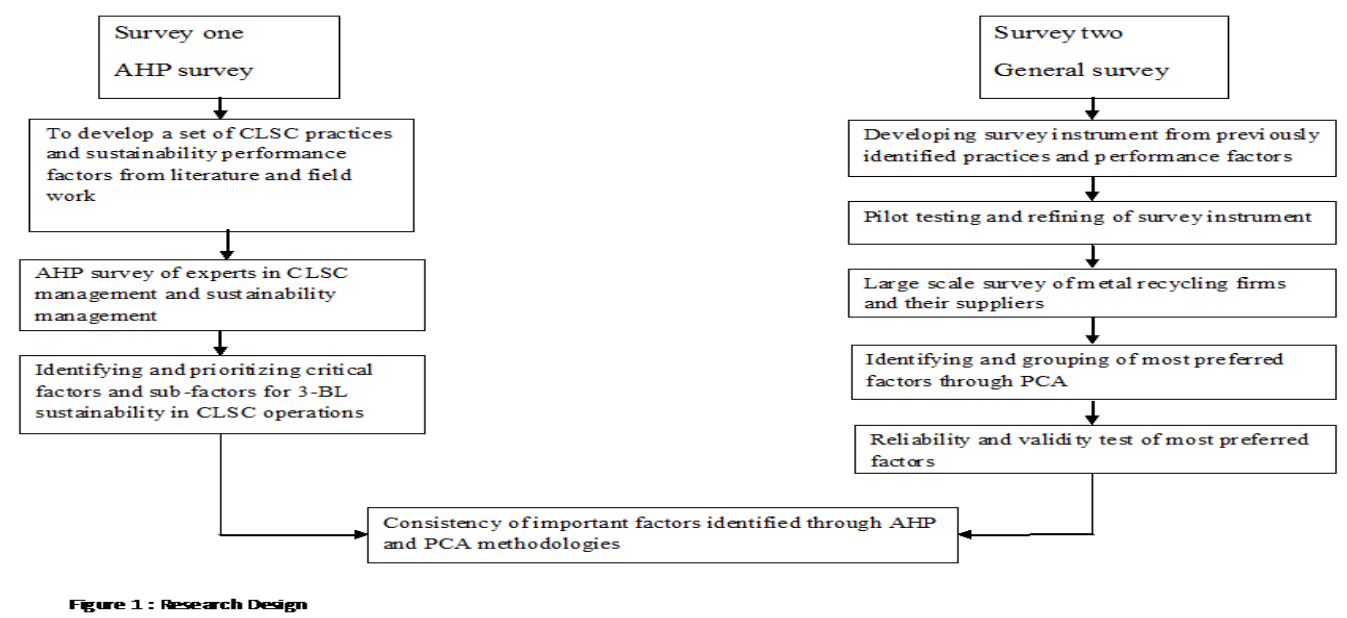

Figure1. Research Design

\subsection{The AHP survey: Prioritizing and assigning ranks to critical factors 3.1.1. Data Collection}

A questionnaire was prepared to evaluate and prioritize the factors identified previously and were arranged in accordance with the matrix as suggested by Saaty [46]. The questionnaire was developed based on four dimensions of operations management and two dimensions of performances related to CLSC. The management dimensions include: (1) Strategy, (2) Operations, (3) People, and (4) Structure and Infrastructure, while performance dimensions included (5) Business performance and (6) 3-BL Sustainability performances, as identified in the literature review. A total of 25 experts, having relevant experience were selected for AHP survey and they all agreed to respond. The respondents included top industry leaders (6 nos.), academics (4 nos.), and managers (15 nos.) from metal recycling supply chains and sustainability fields. A limited number of people, possessing thorough knowledge of the subject matter are required for evaluating identified factors and it is not necessary to involve many respondents [55].

\subsubsection{Findings and discussions of AHP Survey}

The hierarchy levels of AHP survey factors are shown in Figure 2. The commercial software packages (i.e., Expert Choice TM) was used for making computations. The local weights of all the main criteria and sub-criteria were first calculated. The global priority vector was then calculated combining all successive hierarchical levels in each matrix, as per standard AHP method. 


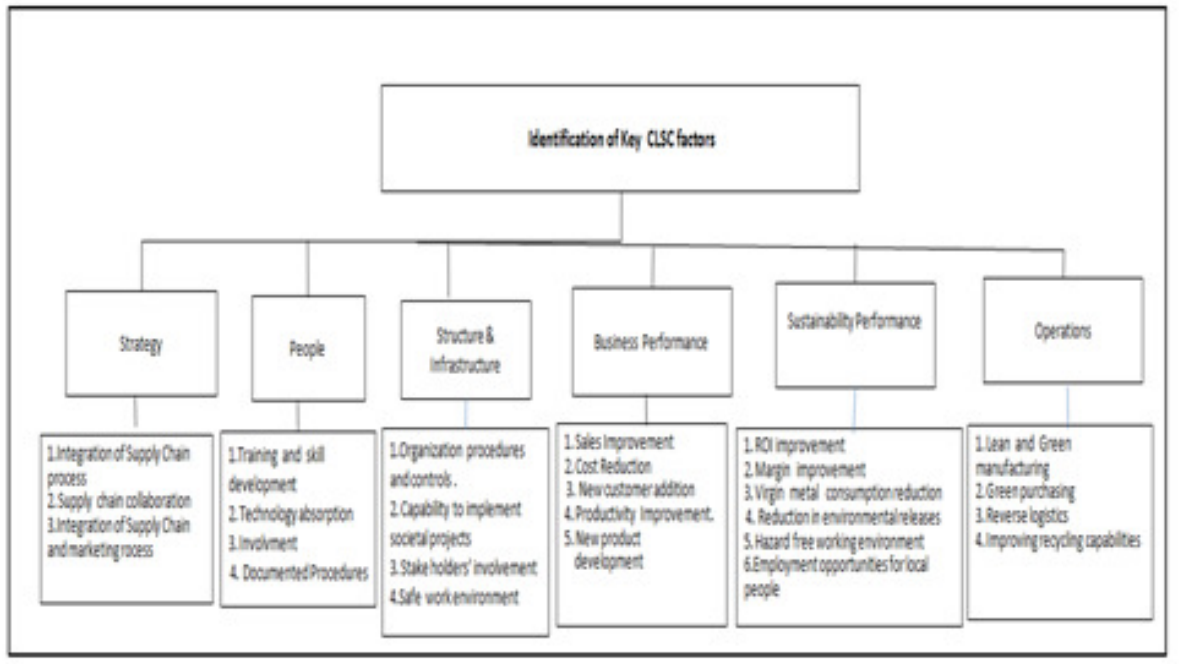

Figure 2 Key factors identified in AHP survey

The evaluation began by determining the relative weight of the six dimensions of CLSC selected for the study. A matrix was prepared to explain and assign comparative importance to each factor, as suggested in literature [46], [47], [48] and results are summarized (Table 1).

Table 1: Prioritization of 3- BL dimensions

\begin{tabular}{|c|c|c|c|c|c|c|c|}
\hline & $\begin{array}{l}\text { Peopl } \\
\text { e (P) }\end{array}$ & $\begin{array}{l}\text { Sustainability } \\
\text { Performance } \\
\text { (SP) }\end{array}$ & $\begin{array}{l}\text { Structure } \\
\text { \& Infra (SI) }\end{array}$ & $\begin{array}{l}\text { Business } \\
\text { Performance } \\
\text { (BP) }\end{array}$ & $\begin{array}{l}\text { Strategy } \\
\text { (S) }\end{array}$ & $\begin{array}{l}\text { Operations } \\
\text { (O) }\end{array}$ & $\begin{array}{l}\text { Eigenvect } \\
\text { or }\end{array}$ \\
\hline $\mathbf{P}$ & 1 & 1 & 2 & 0.25 & 0.25 & 0.5 & \begin{tabular}{|l|}
.09 \\
\end{tabular} \\
\hline SP & 1 & 1 & 2 & 0.2 & 0.2 & 0.5 & .09 \\
\hline SI & 0.5 & 0.5 & 1 & 0.2 & 0.5 & 0.5 & .06 \\
\hline BP & 4 & 5 & 5 & 1 & 0.5 & 4 & .32 \\
\hline S & 4 & 5 & 2 & 2 & 1 & 1 & .26 \\
\hline 0 & 2 & 2 & 2 & 0.25 & 1 & 1 & .17 \\
\hline CR & \multicolumn{7}{|l|}{$\mid .09$} \\
\hline
\end{tabular}

The experts' opinions suggest that Business Performance dimension is the highest priority followed by Strategic factors and Operational factors. People factor and 3-BL sustainability performances have been equally rated. Similarly, Table 2 to Table 7 show the factors under each dimension of People, Operations, Structure and Infrastructure, Strategy, Sustainability Performance and Business Performances, and their evaluation results by experts, respectively.

Table 2: Prioritization of sub-factors under People Dimension

\begin{tabular}{|l|l|l|l|l|l|l|}
\hline & HR1 & HR2 & HR3 & HR4 & Eigenvector & \\
\hline $\begin{array}{l}\text { Training and skill } \\
\text { development }\end{array}$ & 1 & 1 & 2 & 0.25 & 0.25 & \\
\hline Involvement absorption & 0.5 & 0.5 & 1 & 0.2 & 0.5 & \\
\hline $\begin{array}{l}\text { Technology } \\
\text { capability }\end{array}$ & 1 & 1 & 2 & 0.2 & 0.2 & \\
\hline Documented procedures & 4 & 5 & 5 & 1 & 0.5 & 1 \\
\hline CI & 4 & 5 & 2 & 2 & & \\
\hline RI & 2 & 2 & 2 & 0.25 & & \\
\hline CR & & & & & & \\
\hline
\end{tabular}


International Journal of Managing Value and Supply Chains (IJMVSC) Vol. 6, No. 3, September 2015

Table 3: Prioritization of sub-factors under Operations Dimension

\begin{tabular}{|l|l|l|l|l|l|}
\hline & OM1 & OM2 & OM3 & OM4 & Eigenvector \\
\hline Lean and green manufacturing & 1 & 1 & 2 & 0.25 & 0.25 \\
\hline Green purchasing & 1 & 1 & 2 & 0.2 & 0.2 \\
\hline Reverse Logistics & 0.5 & 0.5 & 1 & 0.2 & 0.5 \\
\hline Improving recycling capabilities & 4 & 5 & 5 & 1 & 0.5 \\
\hline CI & 4 & 5 & 2 & 2 & 1 \\
\hline RI & 2 & 2 & 2 & 0.25 & 1 \\
\hline CR & \multicolumn{7}{|l|}{.09} \\
\hline
\end{tabular}

Table 4: Prioritization of sub-factors under Structure and Infrastructure Dimension

\begin{tabular}{|c|c|c|c|c|c|c|}
\hline & SI 1 & SI 2 & SI 3 & SI 4 & Eigenvector & \\
\hline $\begin{array}{l}\text { Organizational procedures and } \\
\text { controls }\end{array}$ & 1 & .5 & 5 & 5 & .33 & \\
\hline Stakeholders' involvement & & 1 & 8 & 5 & .52 & \\
\hline $\begin{array}{l}\text { Capability to implement societal } \\
\text { projects }\end{array}$ & & & 1 & 1 & .07 & \\
\hline safe work environment & & & & 1 & .08 & \\
\hline $\mathbf{C l}$ & & & & & & .02 \\
\hline $\mathbf{R I}$ & & & & & & .90 \\
\hline CR & \multicolumn{6}{|c|}{.02} \\
\hline
\end{tabular}

Table 5: Prioritization of sub-factors under Strategy Dimension

\begin{tabular}{|l|l|l|l|l|l|}
\hline & ST1 & ST2 & ST3 & Eigenvector & \\
\hline Integration of supply chain processes (ST1) & 1 & 1 & .5 & .23 & \\
\hline Supply chain collaborations (ST2) & & 1 & .25 & .19 & \\
\hline $\begin{array}{l}\text { Integration of marketing \& supply chain processes } \\
\text { (ST3) }\end{array}$ & & & 1 & .58 & \\
\hline Cl & & & & & .02 \\
\hline RI & & & & & .58 \\
\hline CR & \multicolumn{5}{|c|}{.03} \\
\hline
\end{tabular}

Table 6: Prioritization of sub-factors under Strategy Dimension

\begin{tabular}{|c|c|c|c|c|c|c|c|c|}
\hline & ROI & MI & VM & ER & HF & EO & Eigenvector & \\
\hline ROI improvement (ROI) & 1 & 1 & 2 & .33 & .4 & 1 & .11 & \\
\hline Margin Improvement( MI) & & 1 & 2 & .2 & .2 & .5 & .08 & \\
\hline virgin metal consumption (VM) & & & 1 & .2 & .125 & .5 & .05 & \\
\hline Reduction in environment release (ER) & & & & 1 & .5 & 2 & .28 & \\
\hline Hazard free working environment (HF) & & & & & 1 & 2 & .36 & \\
\hline $\begin{array}{lll}\begin{array}{l}\text { Employment opportunities for local } \\
\text { communities (EO) }\end{array} & \\
\end{array}$ & & & & & & 1 & .12 & \\
\hline $\mathbf{C l}$ & & & & & & & & .025 \\
\hline $\mathbf{R I}$ & & & & & & & & 1.24 \\
\hline CR & & & & & & 2 & & \\
\hline
\end{tabular}


International Journal of Managing Value and Supply Chains (IJMVSC) Vol. 6, No. 3, September 2015

Table 7: Prioritization of sub-factors under Business Performance Dimension

\begin{tabular}{|l|l|l|l|l|l|l|l|}
\hline & SIM & CR & NCA & PI & $\begin{array}{l}\text { NP } \\
\text { D }\end{array}$ & $\begin{array}{l}\text { Eigenvect } \\
\text { or }\end{array}$ & \\
\hline Sales Improvement (SIM) & 1 & .2 & .1 & 10 & 10 & .3 & \\
\hline Cost reduction (CR) & & 1 & 2 & .5 & 2 & .19 & \\
\hline New customer addition (NCA) & & & 1 & 1 & .25 & .19 & \\
\hline Employees' productivity improvement (PI) & & & & 1 & 3 & .17 & \\
\hline New Product Development (NPD) & & & & & 1 & .14 & \\
\hline CI & & & & & & & .02 \\
\hline RI & & & & \multicolumn{7}{|c|}{.02} & & 1.12 \\
\hline CR & \multicolumn{7}{|c|}{} \\
\hline
\end{tabular}

The local and global ratings of CLSC factors important for sustainable value creations are presented in Table 8 . The calculations highlight that Integration of marketing and supply chain functions (0.151), Sales improvement (.097), Green Purchasing (.09) and Cost reduction (.061) are considered highest rating factors. The analysis also highlights that sale improvement is approximately as important as green purchasing while it is 1.59 times more important than cost reduction. Experts also considered ROI improvement as important as creating job opportunities for the local communities (.01 and .011 respectively).

Table 8: Local and Global rating summary of CLSC sustainability factors

\begin{tabular}{|c|c|c|c|c|}
\hline Factor & & Sub-Factors & $\begin{array}{l}\text { Local } \\
\text { value }\end{array}$ & $\begin{array}{l}\text { Global } \\
\text { value }\end{array}$ \\
\hline \multirow[t]{4}{*}{ People (P) } & 0.09 & Training \& skill development & 0.409 & 0.037 \\
\hline & & Involvement & 0.193 & 0.017 \\
\hline & & Technology absorption capability & 0.294 & 0.026 \\
\hline & & Documented procedures & 0.104 & 0.009 \\
\hline \multirow[t]{6}{*}{$\begin{array}{l}\text { Sustainability } \\
\text { Performance(SP) }\end{array}$} & 0.09 & ROI improvement (SP1) & 0.109 & 0.010 \\
\hline & & Margin Improvement(SP2) & 0.080 & 0.007 \\
\hline & & Virgin metal consumption(SP3) & 0.051 & 0.005 \\
\hline & & Reduction in environmental releases(SP4) & 0.276 & 0.025 \\
\hline & & Hazardous free working environment(SP5) & 0.361 & 0.032 \\
\hline & & $\begin{array}{l}\text { Employment opportunities for local } \\
\text { communities (SP6) }\end{array}$ & 0.124 & 0.011 \\
\hline \multirow[t]{4}{*}{$\begin{array}{l}\text { Structure and } \\
\text { Infrastructure(SI) }\end{array}$} & 0.06 & Organizational procedures and controls & 0.330 & 0.020 \\
\hline & & Stakeholders' involvement & 0.522 & 0.031 \\
\hline & & Capability to implement societal projects & 0.069 & 0.004 \\
\hline & & safe work environment & 0.080 & 0.005 \\
\hline \multirow[t]{5}{*}{$\begin{array}{l}\text { Business } \\
\text { Performance (BP) }\end{array}$} & 0.32 & Sales Improvement & 0.303 & 0.097 \\
\hline & & Cost reduction & 0.191 & 0.061 \\
\hline & & New customer addition & 0.191 & 0.061 \\
\hline & & Employees' productivity improvement & 0.174 & 0.056 \\
\hline & & New Product Development & 0.141 & 0.045 \\
\hline \multirow[t]{3}{*}{ Strategy (S) } & 0.26 & Integration of supply chain processes(ST1) & 0.230 & 0.060 \\
\hline & & Supply chain collaborations(ST2) & 0.187 & 0.048 \\
\hline & & $\begin{array}{l}\text { Integration of marketing \& supply chain } \\
\text { processes(ST3) }\end{array}$ & 0.579 & 0.151 \\
\hline \multirow[t]{5}{*}{ Operations ( $(0)$} & 0.18 & Lean and Green manufacturing(OMl) & 0.288 & 0.052 \\
\hline & & Green purchasing (OM2) & 0.501 & 0.090 \\
\hline & & Reverse logistics (OM3) & 0.054 & 0.010 \\
\hline & & Improving recycling capabilities(OM4) & 0.146 & 0.026 \\
\hline & & & & 0.997 \\
\hline
\end{tabular}


The second survey aimed at investigating the CLSC operations management practices at strategic and operational levels was conducted on the secondary metal manufacturing firms, their raw material suppliers, and reverse logistics (RL) providers. The respondent list was prepared from the data-base of professional bodies representing metal recyclers in India (ALUCAST, INLZDA and ISRI). Raw material suppliers and RL providers were chosen based on their linkages with India metal recycling industry; either through their offices in India or abroad.

Content validation technique was applied to ensure that chosen factors adequately address the research issue under investigation. In this phase, the questionnaires were mailed to a total of 225 secondary metal manufacturing (such as raw material ingots, billets), units performing additional processing of the secondary metal manufactured in the first phase (such as wire drawing, rolling into channels and sections etc.), 15 raw material supplying firms, and $10 \mathrm{RL}$ service providers, into engineering and automotive components, who are part of automotive and construction industry closed-loop supply chains. For the first survey, out of 250 postal surveys to manufacturing companies, 134 valid responses (54\%) were received,15 questionnaires were returned as the recipients were no longer at that address(i.e. 6\%), 10 surveys were not completely filled (4\%). The surveys were administered between January 2013 and October 2013 and professional software SPSS was used for data analysis. In order to identify fewer factors that are able to account for the observed relationship, exploratory factor analysis (EFA) technique was employed on the 42 CLSC operations and sustainability practices identified in the previous research stages [56]. Principal components having Eigen values more than one were for deriving factors. Orthogonal rotation method (Varimax) with Kaiser Normalization was applied for deriving factor loading due to its simplicity [60]. Only absolute values over 0.4 were considered.

From the original 42 variables which were used in the questionnaires, only 16 were related to each other in order to form dimensions. All variables in this research, based on their mean scores are valued high by the participants. Verification on the majority of survey results for reliability and validity through statistical method is necessary to minimize the potential distortion in accordance with the propensity of the responder [54]. Cronbach's alpha test was performed to gauge the internal consistency of the applied instrument and the resultant value of 0.71 validates the instrument [57], [58]. Measurement validity indicates how closely an instrument measures the constructs it is designed to measure and Kaiser-Meyer-Olkin (KMO) and Bartlett Test of Sphericity are performed to test the validity in PCA methodology. The test results (table 9) suggest that factor analysis was appropriate for these data sets. Factor loadings values were satisfactory as suggested in literature [59].

Table 9: KMO and Bartlett's test

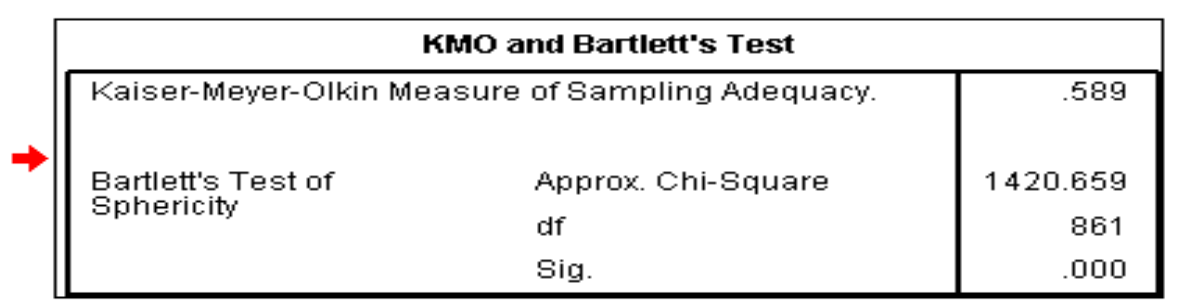

\subsubsection{Findings and discussions of General Survey}

SPSS presents the Eigen values related with each PC (factor) were determined by applying standard methodology through SPSS software. Before extraction, 16 linear components were identified within the data set. Table 10 depicts the list of factors with coding. 
International Journal of Managing Value and Supply Chains (IJMVSC) Vol. 6, No. 3, September 2015

Table 10: Factors and coding

\begin{tabular}{|l|l|}
\hline Factor & Coding \\
\hline Margin Improvement & VAR00001 \\
\hline Integrating CLSC and other business proces ses & VAR00002 \\
\hline Flexible manufacturing & VAR00003 \\
\hline Employment opportunities for local communities & VAR00004 \\
\hline Reduction in release of pollutants & VAR00005 \\
\hline Sustainable supplier development & VAR00006 \\
\hline Collaboration with competitors & VAR00007 \\
\hline Human res ource development & VAR00008 \\
\hline Lean and Green Manufacturing & VAR00009 \\
\hline Technology absorption capability & VAR00010 \\
\hline $\begin{array}{l}\text { Establishingjoint environmental objectives with } \\
\text { suppliers }\end{array}$ & VAR00011 \\
\hline Avoidance of virgin metals & VAR00012 \\
\hline Organizational procedures \& controls & VAR00013 \\
\hline Cost reduction & VAR00014 \\
\hline Efficient Reverse Logistics (RL) & VAR00015 \\
\hline $\begin{array}{l}\text { CLSC risk identification and mitigation } \\
\text { capability }\end{array}$ & VAR00016 \\
\hline
\end{tabular}

Table 11: Descriptive Statistics for important variables.

\begin{tabular}{|l|l|l|l|l|}
\hline & $\mathrm{N}$ & Mean & Std. Deviation & Variance \\
\hline VAR00001 & 146 & 1.8836 & .83468 & .697 \\
VAR00002 & 146 & 2.0822 & .72879 & .531 \\
VAR00003 & 146 & 2.6164 & 1.03231 & 1.066 \\
VAR00004 & 146 & 1.7877 & .60125 & .362 \\
VAR00005 & 146 & 1.8904 & .66564 & .443 \\
VAR00006 & 146 & 2.1575 & .83615 & .699 \\
VAR00007 & 146 & 2.8425 & 1.27408 & 1.623 \\
VAR00008 & 146 & 2.5411 & 1.17518 & 1.381 \\
VAR00009 & 146 & 2.4178 & .64066 & .410 \\
VAR00010 & 146 & 2.2740 & .77478 & .600 \\
VAR00011 & 146 & 2.2534 & .89297 & .797 \\
VAR00012 & 146 & 2.3562 & .65115 & .424 \\
VAR00013 & 146 & 2.5411 & .78016 & .609 \\
VAR00014 & 146 & 1.9589 & .83770 & .702 \\
VAR00015 & 146 & 1.9041 & .74583 & .556 \\
VAR00016 & 146 & 2.2055 & .76038 & .578 \\
Valid N (list wise) & 146 & & & \\
\hline
\end{tabular}

The 16 variables identified in Table 10 are described in Table 11. The Eigen value of a particular factor is indicative of the variability caused by that particular factor in the data. For example the first factor (table 12), having maximum Eigen value indicates that maximum data discrepancy is due the first factor. Similarly, second factor having the second highest value causes second most discrepancy in the data and so on. In the present study, as presented (table 12), the first seven components are strongly associated with discovered factors and account for 60.850 percent variability in the data. After rotation, the sum total of variability due to first seven components remains same (i.e. 60. 850 percent). However, the variability due to individual component has changed. For example, the data variability due to first component, which was 13.106 percent, has changed to 9.34 percent after rotation.

Through of factor analysis, the initial 42 CLSC sustainability practices (independent variables) and performances (dependable variables) have reduced to seven factors. The factors were assigned nomenclature pertaining to individual's distinguishing features as suggested by Kim \& Mueller [60]. In this study, the following seven factors were extracted (Table 12):

'Structure and infrastructure', 'Business performance', 'Sustainable manufacturing', 'Green purchasing and distribution', 'Resource redundancy', '3 -BL Sustainability performance', and 'Business process integration\& collaboration' 
Table 12: Total Variance Explained (after Varimax rotation) Extraction Method: Principal

\begin{tabular}{|c|c|c|c|c|c|c|c|c|c|}
\hline \multicolumn{10}{|c|}{ Total Variance Explained } \\
\hline \multirow[t]{2}{*}{ Component } & \multicolumn{3}{|c|}{ Initial Eigenvalues } & \multicolumn{3}{|c|}{ Extraction Sums of Squared Loadings } & \multicolumn{3}{|c|}{ Rotation Sums of Squared Loadings } \\
\hline & Total & $\%$ of Variance & Cumulative $\%$ & Total & \% of Variance & Cumulative $\%$ & Total & $\%$ of Variance & Cumulative $\%$ \\
\hline 1 & 2.097 & 13.106 & 13.106 & 2.097 & 13.106 & 13.106 & 1.492 & 9.324 & 9.324 \\
\hline 2 & 1.683 & 10.521 & 23.627 & 1.683 & 10.521 & 23.627 & 1.448 & 9.048 & 18.372 \\
\hline 3 & 1.319 & 8.244 & 31.871 & 1.319 & 8.244 & 31.871 & 1.425 & 8.907 & 27.280 \\
\hline 4 & 1.295 & 8.091 & 39.962 & 1.295 & 8.091 & 39.962 & 1.415 & 8.841 & 36.121 \\
\hline 5 & 1.238 & 7.740 & 47.702 & 1.238 & 7.740 & 47.702 & 1.393 & 8.709 & 44.829 \\
\hline 6 & 1.079 & 6.745 & 54.447 & 1.079 & 6.745 & 54.447 & 1.320 & 8.251 & 53.080 \\
\hline 7 & 1.024 & 6.403 & 60.850 & 1.024 & 6.403 & 60.850 & 1.243 & 7.770 & 60.850 \\
\hline 8 & .994 & 6.214 & 67.065 & & & & & & \\
\hline 9 & .929 & 5.809 & 72.873 & & & & & & \\
\hline 10 & .816 & 5.101 & 77.974 & & & & & & \\
\hline 11 & .759 & 4.741 & 82.715 & & & & & & \\
\hline 12 & .663 & 4.145 & 86.861 & & & & & & \\
\hline 13 & .611 & 3.819 & 90.680 & & & & & & \\
\hline 14 & .586 & 3.665 & 94.344 & & & & & & \\
\hline 15 & .460 & 2.878 & 97.222 & & & & & & \\
\hline 16 & .444 & 2.778 & 100.000 & & & & & & \\
\hline
\end{tabular}

The first factor, 'Structure and infrastructure', accounted for 9.32 per cent of the variance in the data. The second factor 'Business performance' accounted for 9.04 per cent, the third factor 'Sustainable manufacturing' accounted for 8.90 per cent, the fourth factor 'Green purchasing and distribution', accounted for 8.84 per cent, the fifth factor 'resource redundancy', accounted for 8.70 per cent, the sixth factor '3- BL Sustainability performance', accounted for 8.25 percent of the variance, and the seventh factor 'Business process integration \& collaboration' accounted for 7.77 percent of the variance. These seven factors together accounted for 60.85 per cent of the total variance in the data.

Table 12 presents the exact criteria that were grouped under each factor. The first factor, 'Structure and Infrastructure' consisted of two variables: Organizational procedures \& controls and CLSC risk identification and mitigation capability. The second factor, "Business Performance" consisted of one variable: margin improvement. The third factor, "Sustainable Manufacturing" consisted of two variables: Green and Lean manufacturing and Avoidance of virgin metals. Similarly, "Green Purchasing and Distribution" factor consisted of four variables: Sustainable supplier development, establishing joint environmental objectives with suppliers, Material Cost reduction and Efficient Reverse Logistics (RL). Factor "Resource Redundancy", consisted of two variables: Human resource development and Flexible manufacturing. Factor "3BL sustainability performance" consisted of three variables: Employment opportunities for local communities, Reduction in release of pollutants, and Technology absorption capability, and factor "Business Process Integration and Collaboration" consisted of two variables: Integrating CLSC and other business processes and Collaboration with competitors.

\section{CONCLUSION AND DISCUSSION}

This study identified the most critical CLSC factors contributing to metal recycling 3- BL sustainability. Important conclusions can be summarized as follows. Although the most important business category for achieving sustainability was the business performance $(0.32)$; strategy (0.26) and operations management $(0.26)$ were two other important categories. The five most important factors, in order of highest Global Values were integration of supply chain and marketing processes (0.151), sales improvement (.097), green purchasing (0.90), cost reduction (0.061) and integration of supply chain processes $(0.060)$. 
The results of the study were reconfirmed using statistical analysis. Selection of important factors by bundling the factors extracted through PCA and factors within the AHP priority ranking group, the results were statistically analyzed. The results obtained by applying PCA methodology confirmed the results obtained through AHP method, thus statistically validating the most important factors contributing to CLSC sustainability.

Since this study was primarily done considering CLSC practices in Indian metal recycling industry, the results are most suitable for addressing the sustainability issues in Indian metal CLSC. The ranking of factors or even few factors may be different in developed countries, and hence the results may be applicable partially. But as the researchers suggest that [61], sustainability issues in emerging markets are very similar, results concluded from the present research can be applied to countries such as Pakistan, Bangladesh, and Sri Lanka where similar societal, economic and environmental concerns exist.

\section{REFERENCES}

[1] WCED (World Commission on Environment and Development) (1987).Our Common Future. Oxford, UK: Oxford University Press.

[2] Elkington, J. Cannibals with Forks: The Triple Bottom Line of 21st Century Business, New Society Publishers: Stony Creek, CT, USA, 1998.

[3] Carter, C. R., \& Rogers, D. S. (2008) "A framework of sustainable supply chain management: Moving toward new theory", International Journal of Physical Distribution and Logistics Management, Vol.38, No. 5, pp360-387.

[4] Correa, H.L., Xavier, L.H. (2013) "Concepts, design and implementation of Reverse Logistics Systems for sustainable supply chains in Brazil", Journal of Operations and Supply Chain Management, Vol. 6, No.1, pp1 - 25.

[5] Beamon, B. M., (1999) "Measuring supply chain performance", International Journal of Operations \& Production Management, Vol. 19, No. 3, pp. 275-292.

[6] Browne, J., Dubois, D., Sethi, S.P., \& Steke, K.E.,(1984), “Classification of manufacturing systems" The FMS Magazine. Vol.2, pp 114-117

[7] Clift Ronald, (2006) "Sustainable development and its implications for chemical engineering", Chemical Engineering Sciences, Vol. 6, No.13, pp 4179-4187.

[8] Meadows, D. H., Meadows, D. L., Randers, J. and Behrens, III, W. W. (1972), The Limits to Growth - A Report for the Club of Rome's Project on the Predicament of Mankind, London: Potomac Associates Book, Earth Island Ltd.

[9] Chien, M.K., \& Shih, L.H. (2007a) "An empirical study of the implementation of green supply chain management practices in the electrical and electronics industries and their relation to organizational behaviour", International Journal of Science and Technology, Vol.4, No.3, pp383394. ISSN: 1735

[10] Freeman, Harry M. et al. (1992), "Industrial pollution prevention: A critical review”, J. Air Waste Management Assoc., Vol.42, No. 5, pp 617-656.

[11] Carrol, C. R., J.H. Vandermeer \& P.M. Rosset (1990) Agroecology, McGraw Hill Publishing Company, New York.

[12] Seuring, S. \& Müller, M. (2008) "From a literature review to a conceptual framework for sustainable supply chain management”, Journal of Cleaner Production, Vol. 16, No.15, pp16991710 .

[13] Mentzer, J. T., DeWitt, W., Keebler, J. S., Min, S., C. D., \& Zacharia, Z. G. (2001) "Defining supply chain management", Journal of Business Logistics, Vol. 22, No.2,pp 1-25.

[14] Sarkis, J. (Ed.) (2001). Greener Manufacturing and Operations: From Design to Delivery and Back. Sheffield, UK: Greenleaf.

[15] Rogers, D.S., Lambert, D.M., Croxton, K.L., Garcia-Dastugue, S.J. (2002) "The returns management process", International Journal of Logistics Management Vol. 13, No.2, PP 1-18.

[16] Linton, J., Klassen, R. and Jayaraman, V. (2007), "Sustainable supply chains: an introduction", Journal of Operations Management, Vol.25, No.6,pp 1075-82.

[17] L. N. Van Wassenhove, \& Guide, V. D. R., Jr., eds. (2003a).Business Aspects of Closed-Loop Supply Chains. Carnegie Mellon University Press, Pittsburgh. 
[18] Nunen J,van, Zuidwijk RA.(2004) "E-Enabled closed-loop supply chains", California Management Review Vol. 46, No. 2, pp 40-54.

[19] Gounaris, S. P., (2005) "Trust and commitment influences on customer retention: insights From business-to-business services", Journal of Business Research, Vol 5. 58, No. 2, pp. 126-140.

[20] Harland, C.M., (1996) "Supply chain management relationships, chains and networks", British Journal of Management, Vol. 7, pp. 63-80.

[20] N, Seman., N, Zakuan., A, Jusoh., \& M, Shoki (2012), “ Green supply chain management: a review and research direction", International Journal Of Managing Value And Supply Chains Vol. 3, No. 1, March 2012

[21] Tchobanoglous, G., Theisen, H. and Vigil, S. A. (1993), Integrated Solid Waste Management, McGraw Hill Publishing Company, New York.

[22] Michael W. Toffel (2003)“The Growing Strategic Importance of End-of-Life Product Management," California Management Review, Vol. 45, No. 3, pp102-129.

[23] Norgate, T. E.,\& Rankin, W. J.(2002b) " The role of metals in sustainable development, Green Processing, Cairns, pp 49-55.

[24] Bittoo-Khatri, J., Srivastava, M. (2014), "Sustainable Supplier Selection- A Case of Indian SME”, Book Chapter 35, Springer India, 2014. S. Chatterjee et al. (eds.).Managing in Recovering Markets, Springer Proceedings in Business and Economics. DOI 10.1007/978-81-322-1979-8.

[25] Collis, J. \& Hussey, R. (2009) Business Research: A practical Guide for Undergraduate and Postgraduate Students, 3rd edition, Basingtoke; Palgrave Macmillan.

[26] Morgan, G., Samircich, L (1980) "The case for qualitative research", Academy of Management Review, Vol. 5, No. 4, pp 491-500.

[27] Marc Winter, A. Michael Knemeyer, (2013) "Exploring the integration of sustainability and supply chain management: Current state and opportunities for future inquiry", International Journal of Physical Distribution \& Logistics Management, Vol. 43, No. 1, pp.18 - 38

[28] Carter, C. R., \& Rogers, D. S. (2008). A framework of sustainable supply chain management: Moving toward new theory, International Journal of Physical Distribution and Logistics Management, Vol.38, No. 5, pp360-387.

[29] Pagell, M. and Wu, Z. (2009) "Building an more complete theory of sustainable supply chain management using case studies of 10 exemplars," Journal of Supply Chain Management, vol.45, No.2, pp. 37-56.

[30] Epstein, Mark J. and Roy, J (2003) "Improving sustainability performance: specifying, implementing, and measuring key principles", Journal of General Management. Vol. 29, pp 2536.

[31] Ferguson, M (2009) "Strategic and tactical aspects of closed-loop supply chains: Foundations and Trends in Technology", Information and Operations Management, Vol. 3, No.2, pp101-200.

[32] Lembke, R.S.T., and Amato, H (2001) "Replacement parts management: the value of information", Journal of Business Logistics, Vol. 22, No. 2, pp149-164.

[33] Kumar, V., Shirodkar, P., S., Camelio, J., A., Sutherland, J., W. (2007), "Value flow characterization during product lifecycle to assist in recovery decisions", International journal of production research, vol. 45, No. 18-19, pp. 4555-4572

[34] J., Frota Neto, G. Walther, J. Bloemhof ,\& T. Spengler (2007), A methodology for assessing ecoefficiency in logistics networks. ERS-2007-036-LIS, Erasmus Research Institute of Management (ERIM). www.erim.eur.nl

[35] Meredith, J. (1993) "Theory building through conceptual methods", International Journal of Operations and Production Management, Vol.13, No.5, pp 3-11.

[36] L, Morana., \& S, Seuring (2011) "A three level framework for closed-loop supply chain management-linking society, chain and actor", Sustainability Vol.3,pp678-691; doi:10.3390/su3040678

[37] Jayaratne, P., Styger, L. \& Perera, N. (2011). Sustainable supply chain management: using the Sri Lankan tea industry as a pilot study.25th Annual Australia New Zealand Academy of Management Conference (ANZAM 201)1 (pp. 1-22). New Zealand

[38] H, Walker., \& N, Jones (2012) "Sustainable supply chain management across the UK private sector”, Supply Chain Management: An International Journal, Vol. 17, No.1, pp 15-28

[39] Barros, A.I., Dekker, R., Scholten, V (1998) "A two-level network for recycling sand: a case study”, European Journal of Operational Research, Vol. 110, pp199-214. 
[40] Cannon, J. P., Doney, P. M., Mullen, M. R., \& Petersen, K. J. (2010) "Building long-term orientation in buyer-supplier relationships: the moderating role of culture", Journal of Operations Management, Vol. 28, No. 6, pp506-521. Doi: 10.1016/j.jom.2010.02.002

[41] Gupta,S., Dangayac,G. S., Singh, A.K., \& Rao P. N(2015), "Analytic Hierarchy Process (AHP) Model for Evaluating Sustainable Manufacturing Practices in Indian Electrical Panel Industries", Procedia - Social and Behavioral Sciences , 189, pp 208 - 216. www.sciencedirect.com

[42] Zhu, Q., Dou, Y. \& Sarkis, J (2010) "A portfolio-based analysis for green supplier management using the analytical network process," Supply Chain Management. An International Journal Vol. 15, No.4, pp. 306-319.

[43] Lu, L.Y.Y., Wu, C.H. \& Kuo, T.C (2007) "Environmental principles applicable to green supplier evaluation by using multi-objective decision analysis," International Journal of Production Research Vol.45, No.18-19, pp. 4317-4331

[44] Golicic, S. (2011) "Implementing mixed methods research in supply chain management", International Journal of Physical Distribution \& Logistics Management, Vol. 42 No. 8/9, pp.726 $-741$

[45] Wamalwal, B., P. (2014), "Sustainable supply chain management as a strategic tool for competitive advantage in tea industry in Kenya", Journal of Management and Sustainability; Vol. 4, No. 3, pp. 157-164. ISSN 1925-4725 E

[46] Saaty, T. L, (1980).The Analytic Hierarchy Process, McGraw-Hill, New York.

[47] Dey, P. K., and W. Cheffi (2012) "Green Supply Chain Performance Measurement Using the Analytic Hierarchy Process: A Comparative Analysis of Manufacturing Organizations", Production Planning \& Control: The Management of Operations, Vol. 24, No.8\&9, pp: 702-720. doi:10.1080/09537287.2013.798088

[48] Bhattacharya, A., P. Mohapatra, V. Kumar, P. K. Dey, M. Brady, M. K. Tiwari, and S. Nudurupati(2013) "Green Supply Chain Performance Measurement Using Fuzzy ANP-based Balanced Scorecard: A Collaborative Decision-making Approach", Production Planning \& Control,Vol.25, No.8, pp 698-714

[49] Zhou Z, Cheng C., Hua B. (2000) "Supply chain optimization of continuous process industries with sustainability considerations", Computers and Chemical Engineering, Vol. 24, pp. 11511158 .

[50] Kurien, G. P., \& Qureshi, M. N (2012) "Performance measurement systems for green supply chains using modified balanced score card and analytical hierarchical process", Scientific Research and Essays, Vol. 7, No.36, pp. 3149-3161.

[51] Petroni A., \& Braglia, M (2008), "Vendor selection using Principal Component analysis", Journal of Supply Chain Management, Vol.36, No.1, pp63-69

[52] Hsu, C.W. \& Hu, A.H., (2008) "Green Supply Chain Management in the Electronic Industry", International Journal Environment Science Technology, Vol. 5, No. 2, pp 205-216.

[53] Shang, K.C., Lu, C.S., Li, S., (2010) "A taxonomy of green supply chain management capability among electronics-related manufacturing firms in Taiwan", Journal of Environmental Management, 91, pp 1218-1226.

[54] Kim, W., Kim, Bong-S., \& Youn, M., K (2012) "Usefulness of analytic hierarchy process (AHP) to determinants win-win growth factor for retailing industry in Korea", African Journal of Business Management Vol. 6, No.14, pp. 4824-4834, DOI: 10.5897/AJBM11.1526

[55] Cheng, E.W.L., \& Li, H. (2001) "Information priority-setting for better resource allocation using Analytic Hierarchy Process (AHP). Information Management and Computer Security, Vol. 2, pp 61-70. http://dx.doi.org/10.1108/09685220110388827.

[56] Tabachnick, B. G., \& Fidell, L. S. (1996). Using multivariate statistics (3rd ed.), HarperCollins. New York:

[57] Nunnally, J. C. (1978). Psychometric theory (2nd ed.). New York, NY: McGraw-Hill.

[58] Brewer, J., \& Hunter, A., (1989), Multimethod research: A synthesis of styles, Newbury park, CA: Sage

[59] Leech N.L., Barrett K.C., Morgan, G.A. (2005), SPSS for intermediate statistics: use and interpretation, (2nd ed.), Lawrence Erlbaum Associates, London, UK -122.

[60] Kim, J. O., \& Mueller, C. W. (1978) Introduction to factor analysis: What it is and how to do it, Beverly Hills, CA: Sage.

[61] Huang, J. (2009), "Contextualization of Closed-Loop Supply Chains for Sustainable Development in the Chinese Metal Industry", PhD Thesis, University of Nottingham 